\title{
Jonas Mekas: poética y práctica del cine-diario
}

\section{Jonas Mekas: poetics and practice of cinema-journal}

\author{
RUBÉN GARCÍA LÓPEZ \\ Universidad Carlos III de Madrid \\ p9prod@gmail.com
}

Recibido: 16-10-2013

Aceptado: 13-03-2014

\section{Resumen}

Jonas Mekas es un nombre fundamental del cine independiente: emigrante lituano a New York a finales de los años 40, creó la revista Film Culture y escribió durante todos los años 60 una importante columna en Village Voice donde promovió el cine más arriesgado y radical de su tiempo. Este artículo analiza los rasgos de su práctica cinematográfica, por la que es acaso el más importante practicante del cine-diario, aquí distinguido del cine autobiográfico a través de la consideración de su trato diferenciado con el cine o el vídeo, la presencia de la corporalidad en las imágenes y el papel del montaje y la narración en su obra.

Palabras clave: cine, mirada, pulso, cuerpo, montaje, narración.

\begin{abstract}
Jonas Mekas is a fundamental name of independent cinema: Lithuanian expatriate in New York at the late 40's, he founded the Film Culture magazine and published an important column in the Village Voice, from where he would promote the most daring and radical cinema of his time. This paper analyses his cinematographically practice, for whom he's perhaps the most important cinema-journal filmmaker, which will be distinguished here from the biographical cinema through his dif-
\end{abstract}


ferent ways of treating cinema and video, his corporal presence in the images and the role of editing and narration through his work.

Keywords: cinema, sight, hand steadiness, body, montage, narration.

\section{Walden: el cine, la vida}

Tomemos el comienzo de Walden (Diaries, notes and sketches) (Jonas Mekas, 1969) [en adelante Walden]. La película es sonora, pero las imágenes no dejan por ello de ser mudas: el sonido no pertenece a lo que vemos. Al no haber correspondencia entre ellos, imagen y sonido aparecen fuertemente singularizados, unidos en la formación de una obra pero separados cada uno en su potencia particular. El sonido irrumpe como una avalancha: un ruido urbano, de ciudad, el metro. El sonido del movimiento de un medio ya de por sí bastante móvil, y que de pocas maneras expresa mejor esta cualidad que a través del sonido, del ruido, su ruido. Al mismo tiempo, tras unos créditos escuetos y veloces, imágenes que contrastan radicalmente con el estruendo: los ojos de Mekas, filmados en lo que parece ser un interior, con una luz tenue [Fig. 1], e imágenes de la naturaleza, en Central Park [Fig. 2]; un invierno que ya promete la primavera: nieve, ramas desnudas recortadas sobre el fondo de un Sol aún frío [Fig. 3]; finalmente, Mekas tocando el acordeón, solo en su casa [Fig. 4]. Ningún sonido de la soledad del cuarto, de la soledad de Mekas; ningún sonido del movimiento de las ramas, del crujir de la nieve o el grito de los niños; ninguna música de acordeón; solo el ruido ensordecedor y casi inidentificable, el sonido de la ciudad que contiene todas esas imágenes.

El plano del Mekas músico sucede además al de las ramas sin intermedio de letrero alguno. No nos es posible establecer una relación entre los ojos de Mekas y el paisaje nevado que les sigue, pero sí existe un letrero que marca y explica la cesura [Fig. 5], hace que no nos perdamos, si es que sobrevivimos a la tormenta sonora que puede marearnos al comienzo. Sin embargo, el siguiente salto viene sin avisar, bruscamente, sin explicación pero con tanta naturalidad como un fotograma sigue al otro. La mayor parte de los cambios de plano en Walden-y la mayor parte de la filmografía de Mekas, por lo menos la realizada en soporte fotoquímico- se darán de esta forma.

La película comienza, por tanto, mostrando entre otras cosas su poder de cambiar de un espacio a otro en cuestión de segundos y sin dar razón de ello. Poder consustancial al del propio cine, entendiendo aquí "cine" tal y como podía hacerse en aquellos años en que Mekas trabajaba y con los materiales con que él lo hacía, es decir: como el arte constituido por imágenes dotadas de duración en tanto imáge- 
nes ${ }^{1}$ y cuyo objeto es eso que llamamos película, consistente en uno o varios rollos de lo que comúnmente se denomina celuloide, y que tiene la característica distintiva, perceptible a simple vista, de ser una tira dividida en una multitud de cuadros llamados fotogramas, en cada uno de los cuales se encuentra impresa una imagen y que, al ser proyectados a cierta velocidad, crean una imagen que dura, que tiene la duración como constituyente esencial. A este hecho podemos asociar algo que llama poderosamente la atención en Walden: su velocidad. La película se abre con el ruido del aire que golpea el micro y de las ruedas chirriantes del metro que recorren el espacio urbano a gran velocidad, una velocidad que no es la del pie humano. Pero tampoco la mirada del cine es la del ojo. Este ve continuidad, ve en plano-secuencia $^{2}$; un paso sigue a otro paso, un metro a otro metro y los parpadeos, asumidos con naturalidad, no interrumpen esta cadencia. Pero el cine, tal y como se ha definido más arriba, no ve así, pues en su constitución material la continuidad tiene una naturaleza paradójica: el continuo se da como fruto de una división que posibilita precisamente la interrupción de toda continuidad. Una película es un rollo que se proyecta seguido, un todo: he ahí la continuidad del cine. Pero ese todo está hecho de partes: en su interior, el universo entero puede cambiar en el ínfimo espacio que media entre un fotograma y otro. El espacio cinematográfico es por tanto discontinuo. Georges Méliès fue el primero en descubrirlo, esto es, en utilizarlo: de un fotograma a otro, un individuo presente físicamente en una habitación podía desaparecer; frente al teatro, en el cine el mundo podía, puede, desconectarse en cualquier momento, en el tiempo de un simple parpadeo.

El cine es una conversión del espacio en tiempo. Un fotograma es un espacio, una fotografía. El cine descubre que si se toman 16 imágenes de una persona a una cierta cadencia y se repiten posteriormente a esa misma u otra velocidad, se creará el movimiento de eso que antes solo eran imágenes inmóviles. El cine tiene como componente esencial el tiempo, pero nace como constituido de una multitud de espacios. Fue a un ilusionista - es decir, un especialista en encontrar puntos ciegos en la realidad física para poder realizar cambios en ella sin que el acto de la transformación sea advertido - a quien correspondió darse cuenta de que estos espacios podían ser escamoteados y trucados aprovechando la distancia entre ellos ${ }^{3}$. En la

\footnotetext{
1 Una fotografía, por el contrario, sería una imagen, pero dotada de duración solo en tanto objeto.

2 Recordemos aquí la afirmación de Pier Paolo Pasolini según la cual el cine "es sustancialmente un infinito plano-secuencia, tal y como es la realidad para nuestros ojos y nuestros oídos durante todo un tiempo en que estamos en condiciones de ver y oír". Cabe matizar que en Pasolini "cine" no es lo mismo que "película". En esta última, al intervenir el montaje, "el presente se convierte en pasado (...); un pasado que, por razones inmanentes al medio cinematográfico, y no por elección estética, tiene siempre características de presente (es decir, es un presente histórico)". Los subrayados son del autor. Pasolini, Pier Paolo, «Discurso sobre el plano-secuencia o el cine como semiología de la realidad», en VV.AA., Problemas del nuevo cine, Madrid, Alianza Editorial, 1971, pp. 66-67.

3 Méliès, Georges, «Las vistas cinematográficas», en Romaguera i Ramió, Joaquim y Alsina Thevenet, Homero (eds.), Textos y manifiestos del cine, Barcelona, Cátedra, 1989. Para más detalles, me remito
} 
pantalla se ve, por ejemplo, una pared, pero en el celuloide son cientos o miles de ellas, cada una separada de la otra por una pequeña línea negra, la velocidad que convierte al espacio inmóvil en espacio que dura, que dura un tiempo, la posibilidad de interrumpir el movimiento, de cambiar el espacio, de introducirle nuevos elementos, de falsearlo, en suma: de romper la continuidad, a veces sin que nadie se de cuenta. A pesar de que Walden está dedicada a Lumière, Méliès fue el primero en descubrir este hecho fundamental del que nace el trucaje pero también, con él, el montaje propiamente dicho, es decir, la no sumisión de la imagen cinematográfica al espacio físico.

Mekas es muy consciente de la conformación material de su medio y sus herramientas, hasta el punto de que puede verse a este como el principal núcleo de su trabajo, determinante fundamental de su estética. Tomemos cierto parlamento de los rollos finales de Walden (rodada, recordemos, en 16mm.): "Eso es el cine, fotogramas. Fotogramas. El cine está entre los fotogramas"4. Concentrémonos, de momento, en la primera frase. El cine está hecho, en el caso de Mekas, de 24 fotogramas por segundo. Es un espacio discontinuo que se suele utilizar para producir imágenes continuas, esto es, que reproducen nuestros procesos perceptivos, pero que puede permitirse, si quiere, cambiar 24 veces en un solo segundo, 24 planos-secuencia, fragmentos de presente, en un solo segundo. A mi juicio, de aquí viene esa velocidad de los diarios filmados de Mekas; los escritos no son así de veloces, aunque no carecen de la ambición de registrar la realidad al tiempo que tiene lugar ${ }^{5}$. Mekas filma su vida, pero atento a las condiciones y posibilidades que presenta su medio. Mira el mundo, pero lo hace a través de la cámara, a través del cine, aceptando las reglas de visión de su instrumento. Eso es mirar a través de una cámara: que con nuestra visión se conjugue otra que no funciona con nuestras mismas reglas. Y el cine-diario no deja de ser el mirar de cuando en cuando el mundo, el propio o ajeno mundo, a través de una cámara. Mirar el mundo, pero con las reglas del cine.

Que el cine es fotogramas, en este ámbito, implica que el cine es un registro6. Instantes después de la frase citada, Mekas recita una peculiar definición del cine, al ritmo del sonido estruendoso de una máquina de escribir. Le escuchamos decir "cine es...", seguido de una serie de elementos entre los que repite, por tres veces,

\footnotetext{
asimismo a mi artículo «Georges Méliès y el espacio cinematográfico», Marginalia (http://marginaliafragmentos.blogspot.com.es/2007/06/georges-mlis-y-el-espacio_06.html).

4 "That's what cinema is, frames. Frames. Cinema is between the frames".

5 Mekas, Jonas, Ningún lugar adonde ir, Buenos Aires, Caja Negra, 2008. Tampoco hay que olvidar el compromiso con la velocidad de algunos señalados miembros de la generación beat como Jack Kerouac, todos los cuales tuvieron trato e incluso amistad con Mekas.

6 "En este ámbito", esto es: en el hecho de que Mekas filma, utiliza su cámara como instrumento de registro. Un fotograma puede también pintarse, rayarse, perforarse, quemarse... Mekas, como buen conocedor del cine de vanguardia, es sobradamente consciente de esto, pero su cine es siempre registro, y ello es esencial a sus planteamientos.
} 
"luz". La luz de los objetos se imprime en la película fotosensible que cubre el soporte y produce una imagen. El cine, como la fotografía, se hace con las imágenes del mundo. Algo debe estar frente a la cámara para imprimir su imagen en el fotograma. De hecho, algo debe reflejar luz para imprimirse, con lo cual podríamos decir que el cine es el arte que permite registrar el mundo del modo en que este mismo se expresa, pues para im-primirse, es decir, meterse dentro de la cámara y fundirse a la película, los cuerpos deben primero ex-presarse, es decir, enviar la luz fuera del modo en que solo ellos pueden reflejarla. Con la luz los cuerpos se expresan; con la luz el cine se imprime. Así el cine-diario, en la práctica de Mekas, aparece como un acto de apertura, la apertura personal de alguien que mira al mundo, que lo contempla con atención, de los grandes planos de parques, montañas o puestas de Sol a los detalles de ramas, hojas, flores, rostros, piel, ropas, gestos, etc., de las personas célebres como Lennon o Warhol a otras del todo desconocidas para nosotros, de los adultos a los niños, los animales, la vegetación o la materia inerte, de acontecimientos públicos como bodas o ruedas de prensa a privados, como comidas en soledad, noches de insomnio, etc. Apertura de Mekas, pero también del diafragma de la cámara, el que permite que penetre la luz que imprimirá la imagen. En definitiva, el cine-diario surge de las dos aperturas mínimas que precisa la producción cinematográfica: la de la máquina y la del individuo que la maneja. La una deja entrar la luz, efectúa la impresión; la otra dirige el foco de esa acción en un acto que suele habitualmente designarse precisamente con el término de "expresión"; es decir, en ese acto de dirigir el acto de impresión, el cámara expresa una atención que es la suya, una dirección que es suya, una tendencia, una, suele decirse, "mirada". El cine imprime la expresión del mundo, su luz, pero esta luz es mostrada bajo ciertas condiciones, las de un cierto ángulo de observación, como si los colores que aplicáramos en un lienzo se tuvieran que mezclar siempre ineludiblemente con otro. Lo cierto es que los cuerpos nunca emiten su propia luz sino que la reflejan, del modo en que les es propio; la luz se muestra siempre bajo cierta luz, en este caso la que refleja a su vez el individuo cuya imagen, precisamente, no se muestra; la luz del mundo se imprime en las condiciones establecidas por una luz, ella misma, no impresa ${ }^{7}$.

Esto puede llevarnos a la otra de las afirmaciones citadas: "el cine está entre los fotogramas", en principio contraria a la anterior. Ciertamente el cine es fotogramas, es el mundo que se imprime, que se expresa, pero también es, debe ser, algo más que esto, porque al fin y al cabo, esto lo tiene ya de por sí la fotografía. Así, a la luz como definitoria del cine añade Mekas, en su lista, el movimiento. También el Sol, porque de él proviene la luz que principalmente reflejan los objetos en condiciones diurnas, y también porque es en condiciones naturales, es decir, con la luz presente

${ }^{7}$ Habitualmente no impresa, por supuesto. En el caso de Mekas, él aparece mucho en sus diarios, filmado por sí mismo o por otros. 
en cada lugar, que Mekas filma, pues no usa focos y ni siquiera fotómetro, pero también habla de "respiración, latidos de corazón". El Sol se liga a la luz, esto al movimiento. Movimientos del cuerpo en este caso, porque la práctica del cine-diario está acaso más ligada al cuerpo que a lo que acostumbradamente entendemos por "mirada". Que el cine está entre los fotogramas quiere decir que el cine no es igual a un fotograma o a unos cuantos, sino al movimiento que los une a todos produciendo una imagen que se mueve. El cine registra el mundo, pero es el primer momento en que la imagen de los objetos, como afirmaba André Bazin, es la imagen de su duración $^{8}$. De hecho, años antes de hablar de imagen-tiempo e imagen-movimiento Deleuze, en «¿Qué es el acto de creación?», lo que decía precisamente es que el cine inventa bloques de movimiento/duración ${ }^{9}$. La imagen cinematográfica puede no moverse- pongamos como ejemplo películas realizadas con imágenes fijas como La jetée (Chris Marker, 1962), Colloque de chiens (Raúl Ruiz, 1977) o Unas fotos en la ciudad de Sylvia (José Luis Guerín, 2007)-, pero lo que no puede es no durar.

"El cine está entre los fotogramas": entre dos fotogramas hay un espacio negro, que nunca se imprime. Es el espacio del parpadeo de la cámara, un espacio equivalente al tiempo que el obturador tarda en cerrarse y volver a abrirse. Un fotograma es inmóvil, pero el espacio negro es índice de un movimiento; entre dos fotogramas hay, por tanto, un movimiento, el que efectúa el paso de un fotograma a otro. Pero entre dos fotogramas está también aquello que produce ese movimiento: el individuo que filma, el que aprieta el gatillo, el que pone en marcha la máquina en el momento deseado durante el tiempo deseado. Yendo más lejos, pero en parte autorizado por estar hablando de cine-diario, se diría: entre dos fotogramas está la vida. Pero podemos quedarnos de momento con el hombre, Jonas Mekas en este caso.

\section{El pulso}

Por otro lado, es obvio que entre los fotogramas no solo hay una persona. Está el hombre... pero también la máquina. El cine de Jonas Mekas varía mucho según esté hecho en cine o vídeo. Este último graba en una cinta, mediante un método de impresión magnético ${ }^{10}$. La imagen ya no se imprime sino que surge de una codifi-

\footnotetext{
8 "Por vez primera, la imagen de las cosas es también la de su duración: algo así como la momificación del cambio”, Bazin, André, ¿Qué es el cine?, Madrid, Ediciones RIALP, 1966, p. 19.

9 «¿Qué es el acto de creación?», en Deleuze, Gilles, Dos regímenes de locos, Valencia, Pre-Textos, 2007, p. 282.

10 Evidentemente hablo del vídeo analógico, cuyo uso inició Mekas en los años 80. La aparición del vídeo digital no hace más que radicalizar lo a continuación afirmado, añadiendo que la pequeñez de las cámaras- y la aparición de nuevas plataformas de exhibición como Youtube- parece animar a hacer películas más pequeñas, con escenas mínimas como las predominantes en el famoso 365 day project (Jonas Mekas, 2007).
} 
cación, aunque la óptica igualmente tiene que recoger la luz de lo que quiere filmar: el mundo sigue estando allí. Pero la cinta de vídeo, si bien consistente como antes en un rollo, es un continuo sin divisiones a la vista, sin cuadraditos impresos con imágenes, una tira negra continua. Y Mekas, en consecuencia, cambia. La imagen se hace continua, sigue al mundo en su movimiento y al cámara en su percepción natural. La película percibe el mundo -ahora sí- en plano secuencia. Como además la cámara tiene micrófono incorporado, el sonido puede ser sincrónico y pertenecer a la imagen: el peso de la realidad se hace entonces mayor. Pero ha de advertirse que la cámara no se hace menos presente, más bien al contrario: si atendemos al momento en que Mekas graba el cadáver de Allen Ginsberg en Scenes from Allen's last three days on earth as a spirit (1997) ${ }^{11}$, rodada en vídeo analógico durante los tres días posteriores a la muerte del poeta, advertiremos con cuánta nitidez se escucha la vida de esa cámara, el sonido de la imagen que se graba, la cinta que gira, la mano que manipula el aparato, por no hablar de la acción del foco automático, es decir, de la reacción de la cámara a las precarias condiciones lumínicas del espacio.

Imagen continua, sonido sincrónico, peso creciente de la realidad filmada en su más vehemente materialidad. Pero en todo esto permanece un elemento que constituye el principal nexo de unión con el cine en $16 \mathrm{~mm}$, aquí perceptible incluso en su sonido: el pulso de las manos de Mekas.

Algunas películas presentan imágenes subjetivas filmadas cámara en mano, con una imagen tambaleante. Pero esto, aunque se puede hacer mejor o peor o ser interesante por otras razones, es inadecuado, ya que la visión humana equilibra los movimientos del cuerpo, los hace naturales porque, en definitiva, así le son. Con la imagen cinematográfica sucede al contrario: un tropiezo en ella es un movimiento violento, brusco. La visión humana se asemeja más a un travelling imperfecto, poco firme, o incluso un plano con steadycam, que a una cámara en mano, donde las sacudidas harán que la imagen no resulte cómoda, mientras que a la visión los pasos no le impiden en absoluto percibir una imagen clara y serena. Mis pasos, a mi visión, no le importan.

Mekas ocasionalmente apoya la cámara, pero el $99 \%$ de las veces la lleva en la mano. No usa nunca trípode, aunque lo único que tenga que hacer es filmar la pantalla de un televisor, como en Lithuania and the collapse of the USSR (2008). Esto implica que hay algo que siempre está presente en sus imágenes, sean estas producidas en formato fotoquímico, vídeo analógico o digital: el pulso, su pulso. Mediante éste, el cuerpo del que filma se contagia a la imagen, porque si llevo la cámara en la mano y no me preocupo por su estabilidad no verá del mismo modo que yo sino de uno en que solo ella puede hacerlo, uniendo en la imagen las características de su visión y la conformación física de aquel que filma: cuán firmes o tré-

11 Esta película es visible en la propia web del cineasta: http://jonasmekasfilms.com/online_materials/\#self_portrait 
mulas son sus manos, su respiración, sus pasos, etc. Dicho de otro modo: en el cinediario según Mekas, la imagen no reproduce el modo en que ven los ojos, sino aquel en que ve el cuerpo. No la mirada, sino el pulso.

El pulso entonces designaría esa cualidad de la imagen por la cual se hace sensible en ella el cuerpo de aquel que la produce. El trato con él puede servir para caracterizar cierto cine: por ejemplo, las películas que recurren a esa imagen que se suele llamar "documental" convierten el pulso en convención, un signo utilizado para denotar realidad mediante el método de emular las grabaciones de los noticiarios, por lo general hechos con cámaras más o menos ligeras llevadas al hombro. En los años 60 y 70 la renovación generacional de casi todas las cinematografías (norteamericana, francesa, japonesa, y un larguísimo etcétera) incluyeron la cámara en mano en su vocabulario después de una larga prohibición que supone una de las características de lo que llamamos "clasicismo"12, en el que el pulso es evitado de forma sistemática. Travellings, grúas y otros sistemas son formas de crear movimientos de cámara que no denoten la presencia humana, de automatizarlos, en una búsqueda de la continuidad perfecta y la neutralidad en el punto de vista, características que ayudan a definir la famosa "transparencia" característica del cine clásico. Actualmente, la tecnología ha llegado de hecho a desarrollar impresionantes máquinas que realizan por sí mismas, convenientemente programadas, movimientos enormemente complejos con una enorme precisión.

Pero tampoco el cine moderno es ajeno al rechazo del pulso, aunque éste no le sea consustancial 13. En El año pasado en Marienbad (Alain Resnais, 1961), narración mental, historia que tiene lugar en algún misterioso espacio ubicado entre el pasado y el presente, la verdad y la ficción, el recuerdo y la mentira, el cine y la realidad, que parece tener lugar en el interior de alguien, aunque nunca sepamos a ciencia cierta quién, Resnais pone en escena unos travellings imponentes, una mirada netamente inmaterial, mirada de nadie, de nadie humano al menos, mirada diríase del espacio o pensamiento mismos. Pues, si pensamos un travelling como imagen subjetiva, ¿a la mirada de quién pertenecería? ¿Quién es capaz de mirar como las cámaras de El año pasado en Marienbad, El desprecio (Jean-Luc Godard, 1963) o Stalker (Andrei Tarkovski, 1979)? Iván Zulueta tuvo esto en cuenta como nadie al escenificar, en Arrebato (1979), un proyecto consistente en el rechazo del pulso la repulsa de toda presencia humana en la imagen cinematográfica - y el logro de

\footnotetext{
12 Como este "clasicismo", que no deja de ser un término convencional por el que referimos la producción cinematográfica que más o menos abarcaría desde los años 20 a 60 del pasado siglo en como mínimo los países culturalmente hegemónicos como Francia, Inglaterra o Estados Unidos, está lejos de ser un bloque uniforme, se pueden encontrar varios ejemplos de cámara en mano en él, pero no por ello dejan de ser excepciones a una regla muy clara, sobre todo en Hollywood.

13 Debo matizar que el presente texto en absoluto considera este rechazo como algo condenable. La valoración de la existencia o inexistencia del pulso es algo tan circunstancial como la de cualquier forma o elemento cinematográfico o de cualquier otra índole. Pero sin duda es algo existente.
} 
una plena independencia cinematográfica gracias a una cámara que acababa decidiendo por sí misma, desde su trípode, cuándo y qué empezar a filmar, y que llegaba en definitiva a ser autora ella misma de una película con el director como protagonista, viviente - si prisionero o no, habría que discutirlo - en un único fotograma de ésta. Ese cine químicamente puro, aislado de todo rastro, pulso, latido o respiración humanas, era lo que buscaba el Pedro P. del film de Zulueta, ni más ni menos que una radicalización del sueño clásico, aquel que se soñaba sueño de nadie, sueño de sueños.

\section{Montaje}

Debe observarse asimismo que el pulso en este sentido puede comportar un cierto bloqueo, o interferencia, comunicativa. De hecho, en una entrevista Mekas llegará a decir que la comunicación no le interesa ${ }^{14}$. En El sentido del cine, Eisenstein explica que la eficacia del montaje reside en que incluye en el proceso creador las emociones y la inteligencia del espectador, quien es obligado a marchar por el mismo camino creador recorrido por el autor al crear la imagen. El espectador ve no solo los elementos representativos de la obra ya terminada, sino que vive también el proceso dinámico de la aparición y composición de la imagen justamente como fue vivido por el autor. Y esto es, evidentemente, el más alto grado posible de aproximación para transmitir visualmente las percepciones e intención del autor en toda su plenitud, para transmitirlos con "esa fuerza de palpabilidad física" con que se presentan ante el autor en su visión y trabajo creadores ${ }^{15}$. Según este planteamiento, el cineasta tiene que crear la imagen de algo mediante fragmentos significativos que en su articulación se sumen hasta formar la imagen total deseada, pues en sí mismos solo representan un aspecto aislado, necesitando que el montaje los relacione con otros para formar la imagen global buscada, de tal modo que en la película resultante el espectador reconstruya el proceso de construcción tal como, en el momento del montaje, lo hizo el director. La comunicación, en este planteamiento, es algo que tiene lugar entre dos mentes; en cierto modo, son las almas las que se comunican. Sin embargo el cine de Mekas es puro cuerpo: el humano de un hombre, el mecánico de una cámara. El pulso, conformando una imagen que no reproduce la de la mirada, genera una imagen ajena en parte al individuo que la pro-

\footnotetext{
14 "La comunicación es mierda. El arte y el cine nada tienen que ver con la comunicación", en «Conversación con Jonas Mekas», Cabeza Borradora, 2 (2003), pp. 27-28. Películas como Scenes from the life of Andy Warhol (Jonas Mekas, 1982), Birth of a nation (1997) o parcialmente la propia Walden pueden dar fe de ello, aunque no así Reminiscences of a journey to Lithuania (1971-1972) o Lost, lost, lost (1976), que serán por ello tratadas seguidamente.

15 Eisenstein, S. M., El sentido del cine, Buenos, Aires, Siglo XXI, 1974, p. 32.
} 
duce, porque no mira como mira él. El pulso no nos permite ver bien los árboles, las caras, etc. El uso del temporizador y otros elementos similares genera imágenes imposibles para la percepción humana, pero el pulso, siendo totalmente humano, produce una imagen que no se identifica con los ojos, la mente, la conciencia -eso que justamente se acostumbra a identificar con lo humano-, sino con el cuerpo. El cineasta, al hacer cine, trata de mostrar las cosas tal como él las ve para comunicarlas tal como él las ve, siente y piensa, al espectador. Aquí en cambio se trata de un cine asociado con el gesto -el movimiento-, y no ya con la mirada, asociado con lo exterior en mucha mayor medida que con lo interior, aunque enseguida veremos cómo en ocasiones deja de ser así. El cine-diario, en este punto, es un cine que no cuenta, que no reconstruye la vida del que lo hace, que no nos describe sus sentimientos ante lo que sucede. Antes bien, es como si su principio fuese tomar la imagen de los objetos del mundo pero impregnada de uno mismo en lo que más de objeto tiene: en que tiene un cuerpo. La luz del mundo mostrada a la luz no ya de la mente, de la conciencia, del alma, de la mirada, sino del latir de un cuerpo. El pulso contagia al mundo con el crepitar de su propia materialidad, funde con la imagen de las cosas la de la propia respiración, los propios pasos, el pálpito específico de la materia propia.

Además, Mekas no nos cuenta nada de lo que vemos, habla más bien poco. A veces aporta datos escuetos, que sin duda ayudan a situar la película, pero nada más 16 . Se trata solo de imágenes, dirá él mismo, "para mí y para algunos pocos", quizá aquellos que saben qué hay detrás de ellas, o mejor dicho, alrededor. Los que saben lo que pasó tal día y quién es esa chica y quiénes se casan en esa boda, etc. El cine-diario no es cine autobiográfico. Está firmemente radicado en la vida del que filma, pero esto no implica el tener como objetivo reconstruirla o contarla, sino solo ofrecer imágenes de ella, desde ella. Imágenes de una vida, sin más datos, sin nombres, sin anécdota. ¿Cómo monta Mekas sus imágenes? Sin duda, rara vez piensa en realizar una reconstrucción. En Eisenstein y casi todo el cine narrativo, se trata de reconstruir uno o varios acontecimientos que habrán a su vez de articularse entre ellos en orden a una conclusión determinada, y para ello disponer una serie de piezas de una manera concreta y en nada azarosa. En Walden no se reconstruye ningún acontecimiento sino que se está dentro de él, se recogen una serie de imágenes y acaso sonidos que no tienen por qué crear una imagen del acontecimiento considerado globalmente ni menos aún como engranaje de una maquinaria que conduzca por progresión a alguna parte, y que además en numerosas ocasiones se encuentran

\footnotetext{
16 Hay que considerar que en Walden las declaraciones más explícitas (sobre qué es el cine, o sobre el sentido del film) tienen lugar en su parte final, es decir, después de por lo menos dos horas de metraje, como si Mekas quisiese ser fiel al hecho de que sus palabras son posteriores al rodaje del material, por lo que las sitúa cuando este se halla cerca de su conclusión y nosotros mismos hemos tenido tiempo suficiente para reflexionar sobre él por nuestra cuenta.
} 
dispuestas de forma azarosa y caótica. Dicho de otro modo, el corte de montaje no tiene casi nunca una fundamentación narrativa. De nuevo en el último tercio de Walden, Mekas dirá: "sin tragedia, sin suspense, sin historia, solo imágenes, solo mira estas imágenes". Muchos identifican el cine con el hecho de contar historias. Mekas siempre hablará del cine poético, cine abstracto, cine experimental, cine independiente... Mekas defiende a Ford, Hawks, Sirk, Hitchcock, pero siempre afirmará la existencia del cine poético, experimental, independiente...: Richter, Deren, Brakhage, Jacobs, Frampton, Snow, Warhol... El cine-diario no es un cine narrativo, si pensamos en el pulso que logra que lo filmado no sea reducible a la conciencia del cineasta, en el montaje que no construye escenas, que no reconstruye acontecimientos, que no busca un desarrollo dramático, y si pensamos en que Mekas no nos dice nada de lo que pasa, no nos aporta datos que nos permitan situarnos con una cierta comodidad en el vendaval que nos lanza encima. El cine no es esencialmente narrativo, no está sujeto a contar historias y ni siquiera a describir acontecimientos. La narratividad comporta una ordenación muy determinada de los materiales, del mundo, e implica hacer que ciertas cosas signifiquen, y que por lo general signifiquen otras cosas que de forma natural, tal como nos las encontramos en la vida cotidiana, no significan. Hay una serie de circunstancias en la historia que producen una significación, aliadas a una muy determinada articulación del material cinematográfico (montaje, encuadres, luz, etc.). Pero ha de observarse que en Walden no hay vivencia alguna reconstruida, de modo que la mirada de nuestro protagonista, que es además el autor, no nos sirve para establecer las significaciones ${ }^{17}$, y que la articulación cinematográfica no establece las relaciones necesarias entre las cosas para que la significación surja, apareciendo en cambio como destellos en un torrente de imágenes veloces, en busca de que solo su imagen se imponga, y sucediéndose de forma clamorosamente azarosa. En Walden las escenas se acumulan, no se almacenan en progresión, es como si la película fuese una caja de escenas en vez de una línea que lleva a un fin. Un rollo de celuloide es ciertamente una suerte de línea, pero en ella puede suceder de todo y además, si bien tiene fin, no implica con ello que éste deba ser significativo. En Walden, el cine-diario no organiza la vida como un argumento sino que la respeta en su sucesión a-significativa, la que podemos experimentar todos a diario.

Entonces, de las imágenes de Mekas en principio solo se puede decir lo que en ellas sucede. La imagen, una imagen, en su estado más primitivo, constituye lo que podríamos llamar una evidencia, algo que no quiere decir nada más que lo que muestra, de la que no se puede predicar nada más que lo que en ella misma sucede (entendiendo por supuesto que en la imagen también "sucede" el encuadre, por

17 Nuevamente hay no pocas salvedades para esto, entre otras las ya referidas palabras de Mekas al final de Walden que nos sitúan en relación a lo mostrado, nos sugieren el modo en que debiéramos relacionarnos con ello. 
ejemplo). La significación precisa articulaciones específicas, no basta cualquier acción humana para establecer un significado, no basta con encuadrar algo, hace falta más esfuerzo, porque significar no es cosa fácil. Godard sería un buen ejemplo de cineasta que, a pesar de la fuerte determinación significativa de la imagen, trata a la vez de mantener máximamente abierta su cualidad de evidencia, fiel a la célebre ecuación que le formuló Manoel de Oliveira según la cual el cine sería "una saturación de signos magníficos bañados en la luz de su ausencia de significación"18. Ha de llegarse al punto en que de las imágenes se pueda predicar poco o nada más que lo que en ellas sucede, como si el núcleo de la vida, o de vivir, radicase en su falta de significado. Mekas es entonces, tal vez, un buen lugar para analizar un posible discurso de la evidencia, donde el sentido se extrae precisamente de su inexistencia. Porque la imagen de la ardilla que recorre las ramas no tiene significado, puede hablarse de un cine que admira en la vida su mero tener lugar, y que además igual que celebra el movimiento del mundo celebra el de su propia herramienta de trabajo, de su propio medio, trabajando de acuerdo con él.

\section{Narración}

Como ya se ha señalado, hay voz y letreros en Walden, pertenecientes a un tiempo posterior al de la filmación, el de la construcción de una película, que comportan por lo tanto un cierto grado discursivo y narrativo. Walden es un ejemplo del ocasional intento de Mekas de mantener ese grado al mínimo, pero no siempre será así. Poco después de esta película y lo registrado en ella ${ }^{19}$, y 27 años después de su exilio forzoso, Jonas Mekas regresa junto con su hermano a Lituania, y vuelve a ver a su familia. Como es de esperar, lleva su cámara consigo y realiza una película, Reminiscences of a journey to Lithuania. En ella, como es de esperar al estar centrada en un entorno rural, aparecen muchos árboles, pero en cierto momento, ante unos concretos, Mekas explica que fueron su hermano Adolfas y él quienes los plantaron, no pudiendo quedarse a verlos $\operatorname{crecer}^{20}$. Esos árboles siguen siendo for-

18 «Godard et Oliveira sortent ensemble», en $J L G$ par JLG, Tomo II, Paris, Cahiers du Cinéma, 1998, p. 270. La declaración completa de Oliveira sería: "Qui, mais si les signes y sont effectivement tout aussi imcompréhensibles, ils sont par contre plus nets et plus visibles. Ce que j'aime dans ce film, c'est la clarté des signes alliée à leur profonde ambiguïté. C'est d'ailleurs ce que j'aime en général au cinéma: une saturation de signes magnifiques qui baignent dans la lumière de leur absence d'explication. Voilà pourquoi je crois au cinéma". El film al que se refiere Oliveira es Allemagne anné 90 neuf zéro (Jean-Luc Godard, 1991).

19 Walden recoge imágenes y sonidos de los años 1964 a 1968. El viaje que realizaron Jonas y Adolfas Mekas a Lituania tuvo lugar en el verano de 1971.

20 No es el único caso similar en la filmografía de Mekas: $A$ walk (1990) comienza con el cineasta mostrando dos árboles en una lluviosa calle del Soho neoyorquino, mientras cuenta cómo fueron plantados allí por Georges Maciunas y él mismo en los años 60, frente a la sede de Fluxus. 
mas plenas y vivientes celebradas en su inmediatez, pero ahora también tienen una historia. El encuentro con el pasado, que nunca se perdió de vista pero que a partir de aquí comienza a ser reconstruido, empieza a hacer narrativo el cine de Mekas, que en cierto modo rehace, re-cuenta, en esta película el viaje que le sacó de su país, comenzando a modo de prólogo con el encuentro de EE.UU., el descubrimiento de que empieza a sentirse a gusto allí, a sentir ese lugar como su hogar, y continuando con el retorno a Lituania, donde Mekas descubre que el exiliado nunca ya puede volver a su tierra, para de allí partir a Viena, el lugar adonde intentó huir en los años 40 y al que nunca llegó, al ser capturado en el camino. Pero esta vez sí lo consigue, y lo que allí nos muestra no deja de ser lo que absorbió su vida más tarde, el arte de vanguardia: encuentros con Hermann Nitsch, Peter Kubelka, Ken Jacobs... y finalmente la quema de un viejo mercado vienés que arde, un resto de la vieja Europa que desaparece, la que Mekas vio arder in situ y la que abandonó interiormente abrazando el arte y vida americanos de los sesenta: en cierto modo un cierre circular, que retorna al prólogo del film. Hay, en suma, una historia en ciernes, que quiere contarse a través de la crónica de un viaje no muy largo pero enormemente significativo, una historia que emerge de la unión de los diversos tiempos de una misma vida, el contacto de una imagen del presente con el recuerdo de su pasado. Ahora bien, para que la significación surja, para que la narración comience a tener lugar y se dé la reconstrucción, es preciso que se ponga nombre al pulso y se establezca un contacto preciso con la subjetividad del autor, la vida, pensamientos y recuerdos de Mekas, lo que se dará principalmente a través de su voz, que reinstaurará la comunicación entre almas, entre universos interiores en un grado ahora sí mucho mayor del presente en Walden.

El siguiente gran paso de los diarios filmados, al menos en esta dirección, será Lost, lost, lost, más una autobiografía en imágenes que un diario fílmico en el sentido aquí expuesto, entre otras cosas porque en su interior se escenifica la génesis de Walden, su lugar en la vida de su autor. El film comienza con sus primeros años en EE.UU., su vida en Brooklyn con los exiliados lituanos. Mekas reflexiona sobre su decisión de sostener un diario filmado: no perder su vida del modo como sentía haber perdido su niñez. El cine-diario como resistencia a la pérdida de la memoria, a la pérdida de la propia vida, y como reacción a la experiencia de haber sido arrancado del hogar: primero la casa, luego el pueblo, después el país, finalmente el continente. El cine surge del exilio, y es inicialmente un intento de resistencia al poderoso sentimiento de haber perdido un anclaje con la tierra y con la propia historia. El cine es un ejercicio del exilio, un modo de agarrar la realidad, el mundo, registrarlo en su más firme materialidad. Al comienzo, el principal objeto es el mundo de los compatriotas exiliados, muchos de ellos activistas que buscan un modo de regresar o de seguir sintiéndose allí, en la tierra perdida; Mekas, perteneciente entonces a aquel mundo, se muestra atento a gestos y expresividades corporales pre- 
dominantemente melancólicas, mostrando un presente colgado del pasado, vidas que viven en la pérdida, elegías vivientes, cuerpos que rememoran constantemente una tierra y un tiempo que ya se les ha ido, tal vez para siempre, aunque nadie se resigne a ello.

Son momentos en que accedemos a un Mekas documentalista y melancólico, atento a gestos y actitudes, en busca del retrato de esa tristeza propia de sus compatriotas, y de sí mismo. Sin embargo en cierto momento, asfixiado, abandona. Deja atrás Lituania, la vida en esa tierra que no va a volver, se marcha de Brooklyn y se instala en Manhattan. Aquí, comienza el presente: EE.UU., la tierra de los escritores beat, de Fluxus, de Brakhage, Menken, Ginsberg... Mekas crea Film Culture, escribe célebres columnas sobre cine independiente en el Village Voice, funda la Cooperativa de Cineastas... Manifestaciones, exposiciones, proyecciones, happenings, encuentros con artistas o amigos o desconocidos, como la chica que al final de Walden se sienta a esperar la primavera. Presente: del mundo y del cine. Un fotograma es bello y singular como una flor o una mujer que brillan un instante bajo el Sol. Abandonada la temporalidad del exiliado, el cuelgue de los orígenes, Mekas queda libre sin más asidero que el tiempo de las formas vivas o inertes del mundo. Y Walden comienza, el documental muere y el cine-diario explosiona en todo su esplendor. En el rollo final de Lost, lost, lost Mekas, Ken Jacobs y otros acuden al Flaherty Seminar con dos películas de Jacobs bajo el brazo, pero son rechazados. Duermen al pie de la casa donde los cineastas y documentalistas descansan, y se levantan temprano por la mañana, en el campo inundado de niebla. Los cineastas y documentalistas duermen, solo filman cuando quieren, cuando quieren contar algo, decir algo, pero el "filmador"21, el que hace cine-diario, no para nunca. "Monjes de la orden del cine" [Fig. 6]. El cine, como la vida, no se detiene nunca, es movimiento ininterrumpido. Por dormir, los cineastas y documentalistas se pierden la mañana, sus flores, sus árboles, su niebla. Pero esa es precisamente la materia de la que está hecho el cine-diario, los objetos mismos de la vida, con toda su gratuidad y su franqueza, ajena a los discursos de los que duermen porque no tienen que contar nada por el momento. Pero el cine-diario no cuenta: muestra, y toda la potencia de su decir la afianza en este mostrar: el poder de la evidencia. Mostrar el mundo desde un cuerpo y una cámara, con una máquina y una mano, con pulso y parpadeo veloz. Ese es el núcleo de la filosofía del cine-diario: vivir, y vivir con una cámara. Mirar el mundo a través de una cámara por el simple placer de hacerlo. Si te apetece, en alguna ocasión hacer una película con ello.

21 Este término ("filmer", en el original) es el que en la película Mekas utiliza para referirse a sí mismo. 